\title{
E-læringsplatforme - pædagogiske potentialer
}

\author{
Tom Nyvang \\ Ph.d. stipendiat \\ Institut for Kommunikati- \\ on \\ Aalborg Universitet \\ nyvang@hum.auc.dk \\ http://www.hum.auc.dk \\ Michael Pedersen \\ E-learning konsulent \\ CBS Learning Lab \\ Copenhagen Business \\ School \\ mp.11@cbs.dk \\ http://www.ll.cbs.dk
}

Tom Nyvang og Michael Pedersen er redaktører af Tidsskrift for Universiteternes efter- og videreuddannelse $n r .2$ : E-loeringsplatforme-padagogiske potentialer.

\section{E-læringsplatforme - et komplekst felt}

Potentielle e-læringsplatforme findes i form af kommercielle produkter (fx WebCT og Blackboard), gratis open source software (fx Claroline) og systemer, der slet ikke eller i begrænset grad markedsføres som e-læringsplatforme (fx Sitescape, Lotus Quickplace og BSCW). Platformene forbindes i forskelligt omfang med begreber som LMS (Learning Management System), CMS (Course/Content Management System), CMC (Computer Mediated Communication), CSCL \& W (Computer Supported Collaborative Learning og/eller Work) etc. Dertil kommer, at nyttiggørelsen af e-læring og dermed den tilhørende e-læringsplatform i Tidsskrift for Universiteternes efter og videreuddannelse nr. 1 igen og igen er blevet forbundet med pædagogisk og didaktisk nytænkning, organisatorisk omstilling samt tekniske overvejelser.

Allerede her synes det klart, at et velovervejet valg af e-læringsplatform kan kræve et overblik, der er særdeles vanskeligt at opnå. Måske er opgaven endda for kompleks at samle på en person, fordi så tilsyneladende forskelligartede områder som pædagogik, organisation og teknik alle må tages med i overvejelserne. Hensigten med dette temanummer er at give adgang til en række af de overvejelser, forskellige universitetsmiljøer i Danmark har gjort i forbindelse med valg og nyttiggørelse af en e-læringsplatform. Forhåbentlig kan det hjælpe andre og samtidig føre til en dialog, der giver både bidragyderne til temanummeret, andre interesserede og redaktørerne ny indsigt i problemer og løsninger vedrørende valg og nyttiggørelse af elæringsplatform. Hensigten er således ikke at udvikle en kravspecifikation til den ideelle elæringsplatform, som uden problemer kan anvendes af samtlige danske universiteter, da det næppe er et realistisk mål. Derimod vil et andet meget ambitiøst og mere relevant mål, som vi med dette tema kan tage første skridt mod, være at udpege en række overlappende krav, der må opfyldes med henblik på at lette udvekslingen mellem forskellige e-læringsplatforme og andre relevante systemer således, at uddannelsessamarbejder på tværs af universiteterne lettes (se Stig Brostrøms artikel i dette temanummer for uddybning af denne problemstilling). 


\section{Valg af e-læringsplatform - ramme for diskussion af et komplekst felt}

Til støtte af diskussionen af valg og nyttiggørelse af e-læringsplatforme har vi opstillet figur 1, der sammenkæder pædagogiske, organisatoriske, kompetencemæssige og tekniske hensyn. I de følgende afsnit uddybes hver enkelt af de fire hovedkomponenter og relationerne mellem dem. Desuden placeres og diskuteres temanummerets øvrige artikler i forhold til strukturen i figur 1 .

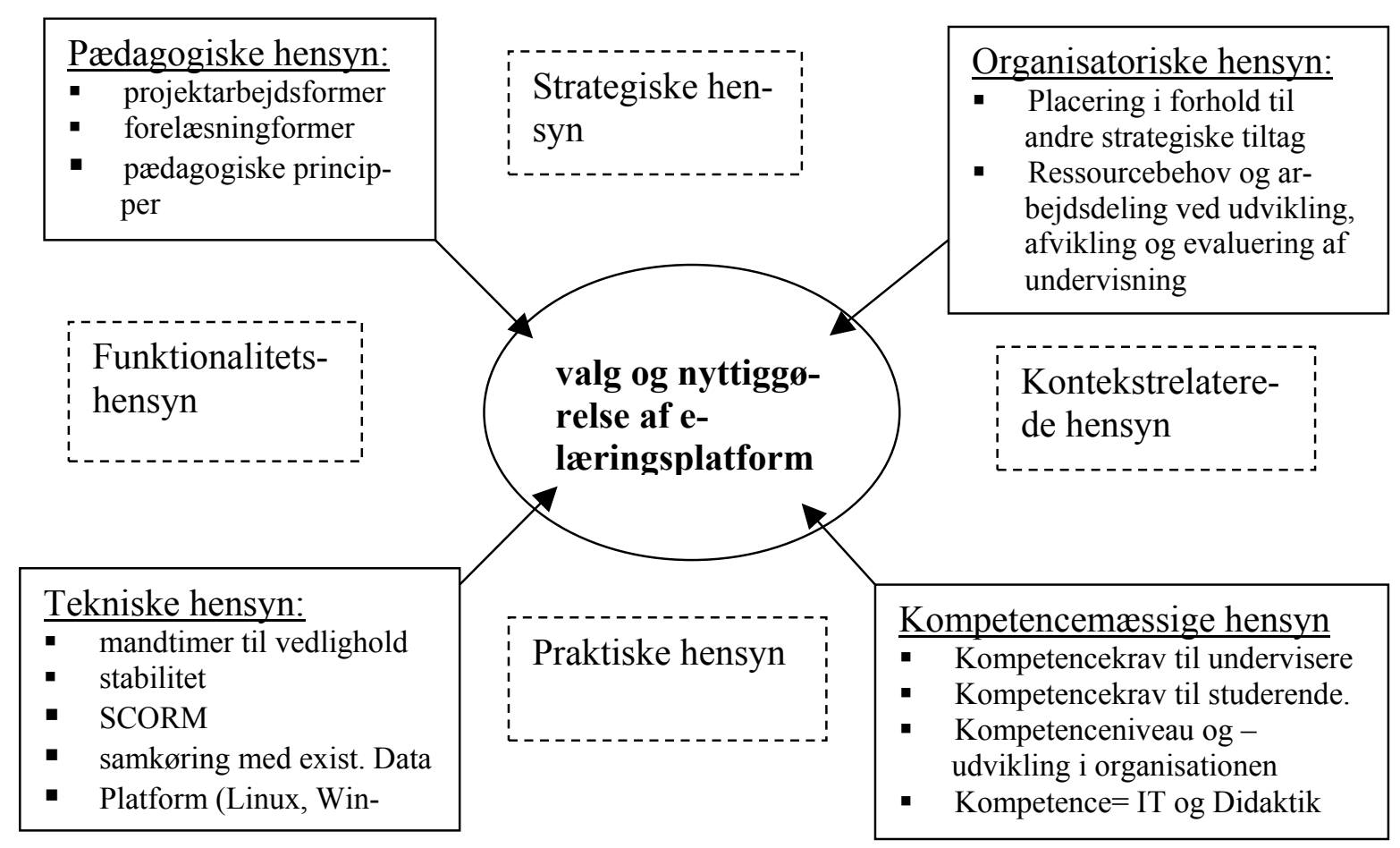

Figur 1. Ramme for diskussion af valg og nyttiggørelse af e-loeringsplatform.

Tanken bag figur 1 er, at der er en nær sammenhæng mellem valg af e-læringsplatform og en række andre forhold i og omkring læringsmiljøet. Alle faktorer inklusiv e-læringsplatformen indvirker på hinanden og ændringer et sted i figuren vil typisk på kort eller lidt længere sigt have konsekvenser andre steder.

\section{Pædagogiske hensyn}

En række kilder har påpeget at pædagogik og IKT er knyttet nært sammen (Tolsby, Dirckinck-Holmfeld and Nyvang). Kilderne fremhæver igen og igen, at ny teknologi ikke i sig selv fører til systematisk og bred pædagogisk innovation. I værste fald kan ny teknologi ligefrem være med til at cementere uhensigtsmæssige elementer af en eksisterende pædagogisk praksis. Ravn et. al skriver således (Ravn, Tofteskov and Heiberg):

Undervisernes padagogiske perspektiv går hånd $i$ hånd med de typer af IT de valger at anvende og hvordan de valger at anvende dem! Derfor må udvikling og anvendelse af IT $i$ undervisningen toenkes $i$ helhed med enhver anden poedagogisk udvikling, da teknologien ellers vil blive anvendt til at forstorke de "traditionelle" undervisningsformer, og således blive en barriere for poedagogisk udvikling!

Denne tendens bekræftes til dels af vores egne erfaringer fra Handelshøjskolen i København og Aalborg Universitet. IKT kan med en relativ begrænset indsats bruges til at støtte kendte pædagogiske tilrettelæggelsesformer gennem fx lettere adgang til mere fleksibel og effektiv koordination, kommunikation og materialehåndtering, som også Morten Hørning er inde på i 
sin artikel. Gissur Jonsson lader også universitets særlige pædagogiske model skinne igennem i sin beskrivelse af RUC's krav til deres e-læringsplatform, der er indrettet så den støtter det problemorienterede projektarbejde. Ole Borch fra Aalborg Universitet samt Michael Pedersen og Lisette Rasmussen fra Handelshøjsolen i København diskuterer ligeledes, hvordan en eksisterende pædagogisk model kunne danne grundlag for valg og/eller valg af e-læringsplatform. På tværs af disse artikler ses dog også tydelige variationer i forhold til den konkrete brug af den valgte e-læringsplatform. Nogen satser meget på projektorganisering og samarbejde, hvorved platformen i høj grad bliver et studieværktøj. I andre sammenhænge ses platformen mere som et værktøj for underviseren i dennes forberedelse og levering af undervisning.

Omstilling til helt nye pædagogiske former kræver længere tid og kræver ikke mindst flere ressourcer (Collis \& Moonen, Dirckinck-Holmfeld \& Fibiger, Lorentsen). På den anden side ønsker vi heller ikke her entydigt at tage afstand fra remediering af eksisterende lærings- og undervisningsformer med IKT. Det kan ikke afvises, at en remediering i et længere udviklingsforløb kan være med til at integrere IKT og på samme tid lægge grunden for en langsigtet pædagogisk udvikling med IKT. Alle disse problemer knyttet til pædagogisk omstilling, vil vi berøre yderligere i forbindelse med specielt de organisatoriske og kompetencemæssige hensyn.

For eksempler på konkrete pædagogiske tilrettelæggelser med innovativ anvendelse IKT henvises til de enkelte artikler i dette og forrige temanummer. Hvis vi ser på de fælles mål for anvendelsen af IKT, som først springer i øjnene, er det forbedret kvalitet, fleksibilitet og effektivitet i de universitære læreprocesser. Midlerne er blandt andet IKT, der bidrager til udvikling af ressourcedeling, kommunikation og koordination. Den konstruktivistiske læringsparadigme er fremtrædende og studieprocesser organiseres, så de studerende i højere grad arbejder på samme måde som forskerne og måske endda i samarbejde med forskerne.

Det gælder også, at gammelkendte og ellers forkastede teknologianvendelser ved pædagogiske innovation kan få ny betydning og nye anvendelser. Nogle af teknikkerne fra programmeret undervisning bruges til at støtte selvstudie uden overhovedet at bygge på samme forældede læringsforståelse. På samme vis kan videotransmission af en underviser, der forelæser for fjernstuderende udgøre en afveksling, give et anderledes billede af en person, der ellers ofte kun kommunikerer skriftligt og træne den studerende i anvendelsen af denne type ressource.

\section{Organisatoriske hensyn}

Der er afgørende for pædagogisk innovation med IKT, at man ikke stiller sig tilfreds, når undervisere, studerende og andre kan betjene en teknologi og anvende den til remediering af en eksisterende pædagogisk praksis (se fx. Henrik Duus og Morten Hørning i dette temanummer). Men deraf følger også spørgsmålet om, hvorvidt specielt underviserne egentlig har rum til pædagogisk nytænkning i forbindelse med ibrugtagning af ny IKT? For at kunne forholde sig til det spørgsmål er det også nødvendigt at overveje, hvad sådan et rum i grunden består af, og hvordan det tilvejebringes? Hertil kommer, at vi her primært taler om universitetsundervisning, som på flere måder foregår i en organisatorisk sammenhæng, der er forskellig fra resten af uddannelsessystemet - mest udpræget $\mathrm{i}$ kraft af institutionens forskningsforpligtigelse og den deraf følgende forpligtigelse til at levere forskningsbaseret undervisning.

Et andet påtrængende spørgsmål vedrører arbejdsdelingen i forsøget på at udnytte mulighederne i en e-læringsplatform i forhold til indfrielse af organisationens strategiske mål. I debatten om valg af platform ud fra et teknisk perspektiv mener vi således, man kan spore et problemfelt omkring hvilke teknisk/administrative opgaver, den enkelte underviser tildeles. Hvor meget teknisk/administrativt arbejde hører egentlig med til at have ansvar for undervisningen? Skal den enkelte underviser fx være ansvarlig for at de studerende har adgang til de 
relevante områder? Er det en rent administrativ problemstilling, hvor en lokal administrator har ansvaret? Eller skal det være system-iboende, at den studerende, som selv har ansvaret for at tilmelde sig et kursus, derved får adgang til de relevante kursusmaterialer?

Det påvises i (Nyvang 2004) at brug af en e-læringsplatform fører til en yderligere komplicering af undervisernes forberedelse. Spørgsmålet er blandt andet om vi forventer, at underviserne vil være i stand til at udvikle eller videreudvikle komplekse IKT-baserede materialer eller skal vi involvere særlige didaktiske og faglige designere? En mulig konsekvens kunne være, at udvikleren af et undervisningsforløb ofte kun i begrænset grad tager del i selve undervisningen, som man har tradition for andre steder i verden. På nuværende tidspunkt har de danske universiteter i vid udstrækning valgt en anden løsning ved på institutions- og fakultetsniveau at oprette IKT-pædagogiske støtteenheder, der kan levere støtte og inspiration til den enkelte uddannelse eller underviser, som ønsker at udnytte en e-læringsplatform.

På baggrund af artiklerne i dette og forrige temanummer ser det ud til, at systematisk pædagogisk innovation med IKT kræver en strategisk satsning - formentlig både på institutionsniveau og i det enkelte studienævn således, at man med et hensigtsmæssigt ressourceforbrug kan udvikle målsætninger, tilvejebringe de rette kompetencer, den nødvendige støtte til udviklingsarbejde og passende IKT. En gennemgående tendens i artiklerne i dette og forrige temanummer er også, at resultater med inddragelse af e-læringsplatforme i pædagogisk innovation følger af iterative udviklingsprocesser.

\section{Kompetencemæssige hensyn}

Kan de studerende og underviserne det, der skal til? - teknologisk OG pædagogisk? Og opstår der eventuelt behov for nye kompetenceprofiler eller en ny arbejdsdeling i organisationen $i$ forbindelse med ibrugtagning af en ny e-læringsplatform og den følgende pædagogiske innovation?

Den basale træning i brug af nye teknologi er flere steder for både undervisere, andre ansatte og studerende gennemført som traditionelle koncentrerede brugerkurser uden meget fokus på den pædagogiske anvendelse af den e-læringsplatform det drejer sig om. Styrken ved korte forløb med fokus på teknologien er, at de hurtigt giver en indtryk den overordnede struktur og funktionalitet i en e-læringsplatform. Svagheden er, at motivationen til at tilegne sig en teknologi ofte er begrænset, når den ikke samtidig indtænkes i den daglige arbejds- og studiepraksis og derved bliver vedkommende og relevant for den enkelte kursist.

Men hvad med de pædagogiske udfordringer (de didaktiske kompetencer) i forbindelse med brugen af teknologien? Michael Pedersen og Lisette Rasmussen præsenterer kort en kursusmodel, der kombinerer den tekniske og pædagogiske dimension i de korte introduktionskurser og følger op med mere avancerede kurser i fx. planlægning af netstøttet undervisning. Henrik Duus fra Handelshøjskolen i Købehavn argumenterer imidlertid også for, at det er gennem praksis, at man får udviklet en pædagogisk praksis:

Min synsvinkel er baseret på mit arbejde i et forskerfoellesskab, som ikke bare har talt og skrevet om e-loering, men som selv har haft fingrene dybt nede i udviklings- og driftsarbejde (se f.eks. Undervisningsministeriet, 2000; Pettersson, 2002; Duus, 2003). Vores syn er her at e-loering ikke kan loeres ved at loese publikationer, deltage $i$ konferencer, kurser og workshops, eller ved at undersøge hvorledes andre har båret sig ad. For os er e-loering proeget af tacit knowledge (Polanyi, 1966; Nonaka \& Takeuchi, 1995) dvs. erfaringsbaseret viden som man kun kan opnå ved at arbejde i tusindevis af timer ved computeren. Intet slår aktionsforskning, hvor man selv designer, udvikler og administrerer e-loringsforløb. E-loering minder herved 
som akademisk felt om kirurgi eller antropologi, idet den akademiske udvikling alle tre steder er kraftigt influeret af personlige praktiske erfaringer (Spender, 1994).

Læses ovenstående citat isoleret kan man få det indtryk, at der ikke er nogen genveje til udvikling af god e-læring, at man i hvert tilfælde må gøre sig alle de nødvendige erfaringer forfra, hvilket vi dog ikke opfatter som artiklens budskab. Pointen er imidlertid vigtig under alle omstændigheder, for den rører jo ved spørgsmålet om, hvordan vi hver især kan fremme egne udviklingsprocesser ved at trække på andres erfaringer? Vi kan ikke levere noget svar her, men blot tilslutte os, at de nødvendige spidskompetencer må tilvejebringes $i$ et komplekst samspil mellem egen aktionsforskning $i$ en given organisation og inspiration udefra.

De studerende synes i denne sammenhæng ofte overset. Hvilke forventninger kan stilles til de studerendes forudgående kompetencer, når det kommer til at kunne studere inden for rammerne af en e-læringsplatform, og i hvilket omfang er der i givet fald plads til, at pensum kan udvides til også at omfatte betjening af en kompleks e-læringsplatform? Der er naturligvis ikke noget entydigt svar, da det vil afhænge af en række faktorer.

\section{Tekniske hensyn}

Det tekniske system er naturligvis en betydningsfuld del af en moderne e-læringsplatform. Stig Brostrøm fremhæver i dette temanummer, at må man gøre sig en række overvejelser vedrørende tekniske forhold, der ikke bare handler platformen isoleret set, men også dens relation til andre tekniske systemer. Hannah Kamstrup Wermuth fremhæver også betydningen af netop dette forhold; integration med universitets eksisterende systemer er afgørende, da alt andet kan føre til administrativt dobbeltarbejde. Det må også overvejes i hvilket omfang, man selv ønsker at udvikle/deltage i udvikling sammen med andre eller om man vil indkøbe en færdig platform klar til brug. Tilsvarende må det afgøres, om man selv ønsker at etablere en driftsorganisation eller vil overlade det til andre at drive sin e-læringsplatform.

I relation til diskussionen af e-læringsplatformes pædagogiske potentialer er der et teknisk forhold, der synes at være af særlig betydning; nemlig i hvilken grad den platform, man vælger, er åben for udveksling af data med tilsvarende systemer. I en tid hvor uddannelsessamarbejder på tværs af institutioner bliver mere og mere udbredte er det således særdeles relevant at forholde sig til, om fx undervisningsmaterialer kan flyttes mellem forskellige systemer eller i hvilket omfang kommunikation mellem studerende eller undervisere på tværs af forskellige systemer kan lade sig gøre.

\section{Afrunding med opfordring til debat}

Dette forord rummer langt flere spørgsmål end svar - også langt flere spørgsmål end dette temanummer kan besvare.

Redaktionen af dette tema finder det derfor meget vigtigt, at der kommer en debat i gang mellem de enkelte universiteters engagerede medarbejdere om, hvordan udviklingen skal forme sig fremover. Hvert universitet har i dag sine løsningsforslag og har truffet de første valg hvad angår platform. Debatten om fundamentet for disse valg er det meget vigtig at få samlet og udtrykt i et fælles forum til fælles glæde.

Vi opfordrer derfor alle til at læse dette temas artikler og indsende yderligere bidrag. Temaet er stadig åbent for nye artikler, hvorfor vi ikke kun opfordrer til at komme med replikker til de eksisterende, men også meget gerne modtager længere sammenhængende fremstillinger og argumentationer.

Endelig opfordrer redaktionen også til deltagelse i temaets workshop som afvikles d. 29.1. (se annonce på http://www.unev.dk/view.aspx?artikel_id=272) 


\section{Litteratur}

Collis, Betty, and Jeff Moonen. Flexible Learning in a Digital World: Experiences and Expec tations. London: Kogan Page, 2001.

Dirckinck-Holmfeld, Lone, and Bo Fibiger, eds. Learning in Virtual Environments. Fredriksberg: Samfundslitteratur, 2002.

Lorentsen, Annette. Aspekter Af Teknologistøttet Fjernundervisning På Universitetsniveau. Vcl-Serien. Vol. nr. 5. Aalborg: VCL, 2000.

Nyvang, Tom. "Teachers Implementing Ict in Higher Education." Virtual Learning Environments. New Ways of Learning in Higher Education. Eds. Lone Dirckinck-Holmfeld and Annette Lorentsen. Aalborg: Aalborg Universitetsforlag (udkommer 2004), 2004.

Ravn, Jakob, Jens Tofteskov, and Birgitte Heiberg. "Forestillingen Om Virkeligheden." At Undervise Med IKT. Ed. Simon Heilesen. København: Samfundslitteratur, 2000.

Tolsby, Håkon, Lone Dirckinck-Holmfeld, and Tom Nyvang. "E-Læring Systemer I Arbejdspladsrelateret Projektpædagogik." Laering I Arbejdslivet. Ed. Knud Illiris. Frederiksberg: Roskilde Universitetsforlag/Samfundslitteratur, 2002. 22. 